\title{
US universities fear fall-out from funding row
}

Washington. Leading US research universities are growing concerned that what initially appeared to be a relatively minor spat in Congress over defence research spending could turn ugly. The results could expose weakening political support for the physical sciences in the aftermath of the Cold War.

The dispute originated in a proposal last month by the House of Representatives' defence appropriations subcommittee, chaired by John Murtha (Democrat, Pennsylvania), to halve the $\$ 1.8$ billion allocated to the Department of Defense (DoD) for research in universities (Nature 369, 694; 1994)

The move is widely seen as a negotiating ploy. When the House approved the measure on 29 June George Brown, chairman of the Science Committee, expressed optimism that the problem will disappear in the Senate - and in the subsequent conference with the House. "There is no fight over this cut because, for all practical purposes, there is

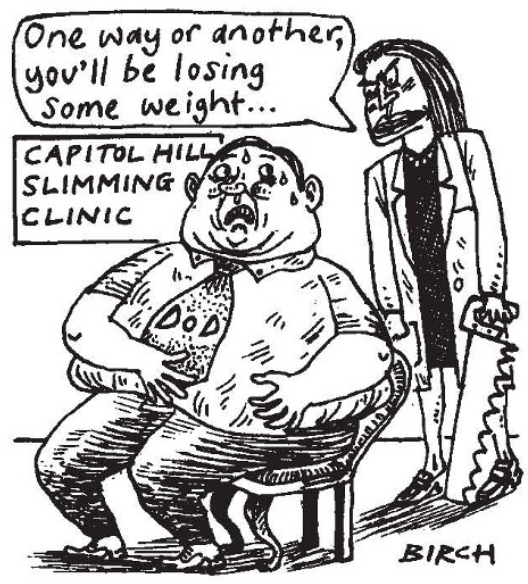

no cut to fight over," said Brown.

But some universities fear that such optimism is misplaced. "I'm very worried that people have been lulled into a false sense of security because the cut seems so large that it [appears] unlikely to happen," says Dick Zare, a chemistry professor at Stanford University, California, who is one of those fighting the proposal. He says the rationale for the proposed cut goes far beyond the disagreement between Murtha and Brown over Brown's efforts to reduce 'earmarking' of funds for pet projects, a reason widely quoted as motivating Murtha's committee.

Murtha has publicly justified the proposed cuts by claiming that universities are wasteful and ungrateful for $\mathrm{DoD}$ support. He has threatened to hold hearings on indirect costs - the universities' least favourite subject. Zare says that both the size of the cuts and the rhetoric that has accompanied them should warn the universities of the seriousness of the situation.

Brown's demands for an end to earmarking have certainly irritated Murtha's com- mittee. But members have told university officials that the earmarking issue is not the reason for the threatened $\$ 900$-million cut. Rather, it is apparently intended to persuade the DoD to select one of six major pending weapon systems for elimination.

The multi-billion dollar systems include new fighters for the Air Force, submarines for the Navy and helicopters for the Army. Murtha is effectively telling the Clinton administration that, unless it can find the courage to cut one of these systems, universities will suffer.

The institutions that would bear the brunt of the cuts, such as the Massachusetts Institute of Technology (MIT), Stanford University and the California Institute of Technology (Caltech), are relying on their friends in the Senate to get them off the hook.

But the Senate defence appropriations subcommittee has never been particularly friendly to such institutions. Many of its members come from states such as South Carolina and Montana whose voters have little sympathy for the plight of élite institutions in California and on the east coast.

University lobbyists in Washington are confident that they can get the $\$ 900$-million cut reduced to $\$ 100$ million or less. But some in the universities are less optimistic. They are concerned that no one outside the universities has rallied to their cause; the computer and aerospace industries, for example, have been ominously silent.

Their silence is curious, as militaryfunded research in universities directly underpins those industries to an extent that is rarely admitted. Across the US university system, for example, the DoD funds 55 per cent of computer science research, 70 per cent of advanced materials research, and 80 per cent of electrical engineering research.

"People don't understand that, in terms of the long-term development of dual-use technologies, the DoD has been the visionary of the federal government," says Ken Campbell of MIT, which received $\$ 70$ million from DoD last year. Campbell points out that university research funded by the Defense Advanced Research Projects Agency (DARPA, now known as just ARPA) virtually created the US computer industry, and is central to the Clinton administration's information superhighway.

During the Cold War, it suited all parties to accept the DoD's role in supporting the élite US engineering schools and fulfilling the basic research needs of key industry sectors. Murtha's threat, intentionally or not, has put this role in the spotlight. Congress must now decide whether or not to continue the arrangement. Colin Macilwain

\section{NIH baffled by drop in applications}

Washington. The US National Institutes of Health (NIH) has experienced a precipitous - but so far unexplained - fall in the number of research grant applications received from young investigators over the past nine years.

According to a report published in Washington last week by the National Academy of Sciences, the NIH awarded research grants in 1985 to 1,308 scientists under the age of 37 . In contrast, the number of young investigators receiving their first NIH grant in 1993 was 527, a drop of 54 per cent. "We're puzzled," admitted Bruce Alberts, president of the academy, when asked where all the young scientists have disappeared to. "We don't know what's going on here."

The data revealing the decline emerged unexpectedly from a study conducted by the academy's National Research Council intended to assess whether young scientists have been disproportionately squeezed out of the system in comparison with senior investigators over the past five years or so, a period in which competition for limited NIH money became unusually intense.

In terms of what NIH calls the 'success rate' - the percentage of successful applicants - young scientists seemed to be holding their own. Shirley Tilghman of Princeton
University, who co-chaired the study with Torsten Wiesel of Rockefeller University, points out that although the success rate of young scientists declined slightly, the drop was not statistically significant.

Only when, late in the study, someone suggested looking at absolute numbers did the 54 per cent fall in young scientists getting NIH grants became apparent. Various explanations have been put forward, but so far each has been rejected as insufficient.

One possible explanation, for example, is that more women are entering the system, and moving up the academic ladder more slowly than their male counterparts. But the fact that women tend to be over 36 when they get their first independent grant does not account for the 54 per cent drop.

Given the uncertainties involved, the academy is now planning a follow-up study. This will both attempt to discover what has happened to the pool of young applicants for NIH grants, and will explore funding patterns at other agencies (and private foundations) that support research in the biomedical sciences.

Barbara J. Culliton

The Funding of Young Investigators in the Biological and Biomedical Sciences. National Research Council. National Academy Press. 2101 Constitution Avenue N.W. Washington, D.C. 20418. 